\title{
The Ambiguous Awareness of Approaching Squeeze-out - Czech CaSe STUdY IN THE EU PERSPECTIVE
}

\author{
Eva Daniela Cvik ${ }^{1}$; Radka MacGregor Pelikánová ${ }^{2}$ \\ ${ }^{1}$ Czech University of Life Sciences, \\ Faculty of Economics and Management, Department of Law, \\ Kamýcká 129, 16500 Praha 6 - Suchdol, Czech Republic \\ ${ }^{2}$ University of West Bohemia, \\ Faculty of Law, Department of Commercial Law, \\ Sady Pětatřicátníků 14, 30614 Plzeň, Czech Republic \\ e-mail: ${ }^{1}$ cvik@ pef.czu.cz; ${ }^{2}$ radkamacgregor@yahoo.com
}

\begin{abstract}
A forced transfer of participating securities, squeeze-out, is an animadverted legal method used by shareholders in the EU, which was significantly changed by the recent Czech recodification. A new duty was imposed upon the majority shareholders for the squeeze-out scenario - to proceed vis-à-vis all minority shareholders in the same manner. They all should get the same compensation, and even the same evening-up. To make this new rule effectively and efficiently applicable, minority shareholders need to be aware of it. The trio of goals of this paper is to describe and explain this duty and to provide a deep, critical and comparative analysis of the awareness of the approaching squeeze-out generating it, while using a set of interrelated hypotheses and relying on primary as well secondary multidisciplinary data in the Czech Republic as well as in the EU. The yield results with comments suggest the insufficient awareness impairing the application of the newly imposed duty in the Czech Republic and the squeeze-outs in general in the EU.
\end{abstract}

\section{Keywords}

Shareholder companies; Minority share; Shareholder; Squeeze-out.

\section{Introduction}

In our global, post-modern, and highly competitive society there re-occur constantly complex prima facia contradictory values and priorities; and both the society [23] and its reflection, the law, need to address and balance them. Naturally, the modern European integration faces these issues [19]. Undoubtedly, the more than one-decade long harmonization of shareholders and shareholder companies relationships, such as via Directive 2004/24/EC on takeover bids ("Takeover Directive"), belongs to them and touches, among other items, the hot squeeze-out matter, business sustainable prosperity $\mathrm{v}$. failure in the economic process of "creative destruction" [24], leading to the total devaluation of investment and elimination of participation [26]. It is highly legitimate because stricter takeover laws increase the protection and wealth gains to shareholders, they do not hurt the bidder and contribute to the efficiency of the market [28]. Squeeze-out is a legal method allowing a shareholder with an at least $90 \%$ share in the shareholder company to become the only, a $100 \%$ shareholder. Generally, a squeeze-out means that the majority shareholder initiates proceedings leading to the transfer of all remaining shares to this shareholder. The majority shareholder has the duty to provide minority shareholders with a financial compensation. The main purpose of the squeeze-out is to allow the majority shareholder to become the only shareholder. The transfer of the 
ownership rights from minority shareholders to majority shareholders occurs after the expiration of one-month period after the publication of the transcript from the general meeting in the Commercial Register. At that moment, minority shareholders lose their participation in the company and their ownership rights to their shares pass, without the will of these minority shareholders, to the majority shareholder. The squeeze-out has often been a subject matter of criticism and while considering "Constitutional" human rights and fundamental freedoms as well as public order and even bonnes mores - good manners [20]. The re-codification of the Private Law with the new Act No. 90/2012 Coll., on Business Corporation ("BCA"), brought about not only terminological changes, but a duty imposed upon the majority shareholder to proceed in the same manner vis-à-vis all majority shareholders as well. This change was linked to the European harmonization. Therefore, Czech minority shareholders should benefit en block by individual compensation settlements and judgments entered vis-à-vis the majority shareholder, who went ahead with the squeeze-out and provided insufficient compensation required to be "even up".

\section{Statement of a Problem and Aims of Research}

Pursuant to EU harmonization, the Czech Republic changed its legislation in order to make the operation of business companies more effective and efficient, while observing the legitimate interests of all stakeholders. This includes minority shareholders who are going to be "expropriated" by the $90 \%$ or more majority shareholder desiring to become the only shareholder and thus administratively simplifying the operation of the given shareholder company. This is endorsed by the BCA, its official explanatory notes [22] and academic commentaries [12]. The squeeze-out in its entirety and its individual aspects, e.g. the calculation of the compensation, are relevant problems basically in all jurisdictions on both sides of the Atlantic. In order to address them, a holistically simplistic requirement needs to be met - the ultimate beneficiary, the minority shareholders to be squeezed-out, they must know that one shareholder is aspiring to reach the legal threshold to launch a squeeze-out, $90 \%$ pursuant to BCA, and that this shareholder intends to really proceed thereafter with the squeeze-out. The knowledge about the squeeze-out method and regime is not fully sufficient if the ultimate beneficiary knows about its theoretic features, but does not note that they are getting themselves to it. The authors of this paper are deeply convinced that the genuine, effective and efficient interpretation and application of the squeeze-out regime in the Czech Republic, as well as in other jurisdictions in the EU, demand awareness of the questions of law related to squeeze-out regulation and, even more, about the questions of fact about its approaching. So far, there have been published only a few studies about the awareness of minority shareholders of the squeeze-out legal regime [5] and no study about the awareness of minority shareholders that the squeeze-out is approaching in their case. Vigilantibus iura scripta sunt. The issue is - do Czech minority shareholders know that squeeze-out is approaching and in general, whether the minority shareholders are effectively and efficiently protected? If not, what can be done about it?

\section{$2 \quad$ Sources and Methods}

This paper is the result of an extensive research of primary and secondary sources and has three fundamental and intra-related goals. Regarding primary sources, a field observation and an original questionnaire search was performed and assessed. Regarding secondary sources, an abundance of Czech, as well as foreign academic and scientific literature focusing on legal or business aspects was explored.

The first goal of this paper is the analytic description of the squeeze-out, both from the perspective of the formal regulation by the Act No. 513/1991 Coll., Commercial Code, and by 
the new regulation by the BCA. The second goal is to assess the data generated by the questionnaire inquiry by the categorical data analysis. The performed questionnaire inquiry and set hypotheses are related to the awareness of minority shareholders of the squeeze-out, i.e. several aspects linked to or generated by the squeeze-out. For purposes of the questionnaire inquiry and its following assessment, the respondents were split into two groups. The first group consisted of respondents having shares of a total value not exceeding CZK 100 000. The second group consisted of respondents having shares of a total value exceeding CZK 100 000. The value of shares was determined based on the registered capital of the company. The following two hypotheses were set based on the questionnaire: $H_{1}-$ The minority shareholder is aware of the aspiration of the purchasing shareholder's to acquire the majority share and $\mathrm{H}_{2}$ - The minority shareholder is aware that, after the purchasing shareholder acquires $90 \%$ of the shares on the company, he or she will proceed with a squeeze-out. The yield data from the completed questionnaires were assessed by the categorical data analysis while using the Czech software program Statistica with the employment of the method of the quantitative signs dependency of the Pearson's Chi-squared Test. The third goal is to compare the squeeze-out issues in the Czech Republic to those in other EU jurisdictions. The critical and comparative studies centered on these goals were processed with the employment of a battery of appropriate methods in order to generate information offering a potential to present original conclusions and valuable suggestions in this field. To achieve the first goal, the descriptive and comparative literature research regarding the old and new regulation of the squeeze-out in the Czech Republic was used. The implied analytic assessment had a deductive nature and was closely linked to the preceding literate research. The second goal was very closely linked to $H_{1}$ and $H_{2}$, which were set based on the experimental investigation and the assessment of the questionnaire's investigation and categorical data analysis and Pearson's Chi-squared Test [18]. The preference was given to the scenario method over econometric and mathematical methods because the combination of a real direct data mining via a questionnaire, complemented by published academic data, seems highly suitable to address $H_{1}$ and $H_{2}$ [3] and ultimately satisfy the second goal. Further, the pertinence of the legal and economic perspectives cannot be overlooked, so it must include both deductive and inductive aspects [15]. In contrast, the third goal had heterogeneous features and thus demanded a more dynamic and multi-disciplinary comparative approach with both qualitative and quantitative aspects since their juxtaposition should not be overplayed [25]. Indeed, the statistical approach is useful, but still impaired by many inherent deficiencies [13]. Due to the nature of $\mathrm{H}_{1}$ and $\mathrm{H}_{2}$, as well as of this paper, the qualitative shade had to prevail. In addition, the paper is basically concerned with the perception of certain legislation and its application, the argumentative legal reasoning [17], reduced axiomatic formula and thoughts. Boldly, the suggestions offered by the literature from various EU member states needs to be confronted with the Czech setting - legislative, academic and, most importantly, practical. In sum, the umbrella method going across the entire paper is the Meta-Analysis able to contrast, combine and reconcile heterogeneous data and results from various sources, fields and studies. Despite the more than one-decade long European harmonization of takeover rules, the national jurisdiction keeps particular features and issues.

\section{Squeeze-out}

The legal foundation of the squeeze-out is the forced transfer of participating securities from minority shareholders when the majority shareholder reaches the threshold of $90 \%$ of the registered capital, or of voting rights, in the company and so minority shareholders lose any real possibility to impose and enforce their will, both in and out of general meetings [8]. The squeeze-out is an instrument, wherein shareholder companies, when such changes occur, in 
which previously dispersed shareholders structure becomes concentrated and by that the functionality of internal mechanisms of the company extinguishes. The duty to call the general meeting, the information duty and other requirements set by the shareholder companies' law becomes, in such a case, a non-functional and anti-business burden. By the leading opinion stream, this is perceived as a disproportionate encumbrance due to the minimal contribution of minority shareholders to the business conduct of the company and as a cause of losses to be borne by all shareholders, both minority and majority ones [7]. The squeeze-out method is perceived as an effective transaction from the business point of view and hence as well socially beneficial [8]. Companies which have used the squeeze-out of minority shareholders argue that this helps them to better administer the company and that they do not need to face abuses of minority shareholders. In certain cases, it happens that minority shareholders intentionally challenge the majority decision and so tie-up business decisions. In sum, the squeeze-out is supposed to be the protection of majority shareholders against minority shareholders who intentionally abuse their rights and present high demands upon the company, by which they disproportionally encumber the company and cripple its effective progress. Minority shareholders do not agree about the squeeze-out, and this is mainly for the reason that it is more beneficial for them to keep shares of a functioning company than to receive a compensation for the shares, forcibly transferred via a squeeze-out; in addition, this compensation often does match their expectations.

\subsection{Czech Legal Regulation of the Squeeze-out before the Private Law Re- codification}

Until 2014, i.e. before the Czech Private Law re-codification, the squeeze-out was regulated by provisions $\S 183 \mathrm{i}$ to $\S 183 \mathrm{n}$ of the Act No. 513/1991 Coll., Commercial Code. This regulation transposed the Takeover Directive and was partially inspired by the Austrian legislation. It has turned out to be highly controversial and missing the goal to protect the minority shareholders [16]. Pursuant to $\S 183 \mathrm{~m}$, in the case of the squeeze-out, minority shareholders had a right to monetary compensation for the forcibly transferred shares in the amount set by the majority shareholder. The majority shareholder had to present a special expert opinion confirming the adequacy of such compensation [27]. Unsurprisingly, the determination of the price linked to the expert opinion has often been challenged before the court by minority shareholders. The leading argument was that the expert who determined the price had been hired and paid to make the expert opinion by the majority shareholder, and that the price merely matched the one set by the majority shareholder themselves. Unfortunately, the Czech law did not follow the Austrian model regarding burden of proof, so, unlike Austrian shareholders, Czech shareholders had to prove what the fair price [16] was. They often did not have access to the company's information and, even if they managed to win the case, these legal suits ended with judgments fixing prices for the forcible transferred shares of the minority shareholders and ordering the majority shareholders to pay the difference between the compensation set by them and confirmed by their expert, and the price fixed by the court. However, the order extended only to different payments to ex-minority shareholders, which were plaintiffs in these court proceedings [2], i.e. such a judgment has not effect vis-à-vis third parties, i.e. the majority shareholder duty to pay the difference extended only to minority shareholders suing the majority shareholder.

\subsection{Czech Legal Regulation of the Squeeze-out after the Private Law Recodification}

After 2014, i.e. after the Czech Private Law re-codification, the squeeze-out has been regulated by provisions $\S 375$ to $\S 394$ of the BCA. Basically, the BCA took over the regulation of the squeeze-out from the Commercial Code and added to it provisions reinforcing the protection of minority shareholders, especially with respect to the judicial 
review of the provided compensation. The BCA newly stipulated for the right for "eveningup", i.e. the right for a judicial review of the adequacy of the provided compensation and the right to obtain the difference between the compensation set and paid by the majority shareholder and the compensation (price) fixed by the court. Minority shareholders can enforce their right for "evening-up" only from the day when the payment of the compensation is due. In addition, minority shareholders must request their "evening-up" from the majority shareholder during a three-month preclusive period running from the day of the publication of the resolution of the general meeting in the Commercial Register. If they do not reach a settlement agreement about "evening-up", the minority shareholder can file a lawsuit in court, i.e. the minority shareholder can start court proceedings for a judicial review of the adequacy of the compensation. The BCA newly reversed the burden of proof in favor of the weak and less informed party, minority shareholders, and hence the majority shareholder has to prove that the compensation set and provided by him to minority shareholders is adequate. Then, the court makes a judgment which is newly binding as well with respect to all other, not legally suing, minority shareholders. Hence the BCA brings a significant change in the enforcement of payments of the difference, i.e. "evening-up" by making the judgment binding for other subjects, who were not parties in the court proceedings but who are in the same position they are as well a minority "squeezed-out" by the same majority shareholder in the same process. Similarly, if one minority shareholder succeeds in reaching a settlement agreement with the majority shareholder about "evening-up" and does not have to go to court, this agreement has the same effect vis-à-vis all other minority shareholders, they all will get the difference payment. However, are they aware of it?

\section{Questionnaire Investigation of the Awareness of the Execution of the Squeeze- out}

Based on set hypotheses, the questionnaire investigation was performed. Questionnaires were given to respondents - minority squeezed-out shareholders - who were forced out after the Czech Private Law re-codification, i.e. already in the regime of the BCA. The respondents and questions for the investigation were selected while relying on the understanding of the new regulation, the preliminary field observation and data generated by the secondary source. This preliminary knowledge induced methodological considerations leading to the selection of criteria, grouping of respondents, and to the well-balanced selection of a battery of heterogeneous intra-related questions suitable to address all goals of this paper, and, naturally, mainly the second goal. Ultimately, it was decided that, for the purposes of the questionnaire investigation and its following assessment, the respondents would be split into two groups. The first group consisted of shareholders with shares of a value not exceeding CZK 100000. The second group consisted of respondents with shares of a value exceeding CZK 100000 . The value of the shares was determined based on the registered capital of the concerned shareholder company. The questionnaires included ten (10) questions of a disjunctive type, i.e. the choice of one of several offered options, five (5) questions leading to dichotomy alternative answers, i.e. Yes/No, and two (2) open questions allowing a free answer. In total, 100 questionnaires were sent to the first group and 100 questionnaires to the second group. The prima facia low number, one hundred, was caused by the strict demand to interview only respondents fitting the given profile, i.e. being squeezed-out under the BCA (applicable less than 3 years) and having a share of a value up to or above CZK 100000 . The return rate of the completed questionnaires was high and reached $95 \%$ in the first group and $95 \%$ in the second group. The yield data was processed by the categorical data analysis by using the program Statistica. The importance level was set at $\alpha=0.05$. For the assessment of the collected data, the statistic method of the quantitative signs dependency pursuant Pearson's Chi-squared Test was used. Conditions for the use of a chi-squared test were met $(n>40)$. 
The main purpose of the questionnaire investigation focusing on questions targeting the awareness of shareholders was to confirm or to reject the set hypotheses about the awareness of minority shareholders about the execution of the squeeze-out and about the purchases of minority shares by the majority shareholder wanting to reach the $90 \%$ threshold.

According to $H_{1}$, the minority shareholder was aware of the aspiration of the purchasing shareholder to acquire the majority share, and according to $H_{0}$ the minority shareholder was not aware of this aspiration of the majority shareholder.

Tab. 1: Contingency table of hypothesis No. $1\left(\mathrm{H}_{1}\right)$

\begin{tabular}{|l|c|c|c|}
\hline & Yes & No & Total \\
\hline The value of minority shares not exceeding CZK 100 000 & 25 & 30 & 55 \\
\hline The value of minority shares exceeding CZK 100 000 & 18 & 22 & 40 \\
\hline Total & $\mathbf{4 3}$ & $\mathbf{5 2}$ & $\mathbf{9 5}$ \\
\hline
\end{tabular}

Source: Authors' own processing

The value of Pearson's Chi-squared Test is $X^{2}=1.931$. The importance level is $\alpha=0.05$ i.e. $X^{2} 0.05(1)=3.841$. Considering the value $X^{2}<X^{2} 0.05(1), H_{0}$, the zero hypothesis, is confirmed. Minority shareholders were not aware of the aspiration of the purchasing shareholder to acquire the majority share, i.e. to progressively get to the $90 \%$ threshold.

According to $\mathrm{H}_{2}$, the minority shareholder was aware that after the purchasing shareholder acquires a $90 \%$ share of the company, he or she will proceed with a squeeze-out, and according to $H_{0}$ the minority shareholder was not aware of this squeeze-out plan.

Tab. 2: Contingency table of hypothesis No. $2\left(\mathrm{H}_{2}\right)$

\begin{tabular}{|l|c|c|c|}
\hline & Yes & No & Total \\
\hline The value of minority shares not exceeding CZK 100 000 & 15 & 40 & 55 \\
\hline The value of minority shares exceeding CZK 100 000 & 21 & 19 & 40 \\
\hline Total & $\mathbf{3 6}$ & $\mathbf{5 9}$ & $\mathbf{9 5}$ \\
\hline
\end{tabular}

Source: Authors' own processing

The value of Pearson's Chi-squared Test is $X^{2}=6.262$. The importance level is $\alpha=0.05$ i.e. $X^{2} 0.05(1)=3.841$. Considering the value $X^{2}>X^{2} 0.05(1), H_{0}$, the zero hypothesis, is rejected. Minority shareholders were aware of the aspiration of the purchasing shareholder to proceed with the squeeze-out. The prima facia discrepancy between the nominal total values for $H_{1}$ and $H_{2}$ and their rejection/confirmation is due to the manner of the statistic calculation implied by the operation of an underlying form of the categorical data analyses via Pearson's Chi-squared Test.

The tested sample of Czech minority shareholders often did not see "the writing on the wall", i.e. did not recognize the active behavior of the majority shareholder to acquire shares in order to reach the threshold for the squeeze-out vis-à-vis the remaining shareholder(s). Even their awareness that the acquisition of $90 \%$ of the shares will or can mean that the majority shareholder will launch a squeeze-out was not impressive. There was not a dramatic difference between the (ambiguous) awareness of the minority shareholders with shares under and over the value of CZK 100 000. However, the minority shareholders had a basic notion about "evening-up" and seemed ready to go ahead with the enforcement, i.e. to attempt the settlement and, if not successful, then follow up with legal proceedings. 

in the $\mathbf{E U}$

The post-Lisbon EU is well aware that an undistorted operation of the single internet market is crucial, that the global, post-modern, knowledgeable society heavily relies on virtualization and employment of information systems and information technologies [21] and that the dynamics of the participation in shareholder companies have an impact on the entire economy and society as such [5]. Already before and especially after the set of 2007 crises, the EU attempted to be pro-active and expressed its commitment to the trio of priorities depicted by the strategy Europe 2020 - smart, sustainable and inclusive growth. This endeavor is backed up by empirical studies indicating serious problems related to misbalancing of control and ownership in shareholder companies linked to the devaluation of minority shares [10]. Hence, the EU drive for public information and fair and non-discriminatory treatment of shareholders had a milestone by the Takeover Directive and keeps going. However, this is not a smooth way, because e.g. the Takeover Directive is the result of over 15-year-long negotiation and its wording is basically the "Portuguese compromise" with a number of optional provisions enabling EU member states to select between them [16]. By the Takeover Directive and related legislative and other instruments, the EU attempted to harmonize the protection of minority shareholders facing a $90 \%$ or $95 \%$ shareholder, making the squeeze-out "public" so that minority shareholders, regarding both the bid to be accepted and the squeeze-out, can be granted a "fair price" [5]. The deadline for the transposition for the Takeover Directive expired one decade ago, so it is highly illustrative to observe certain aspects of the squeezeout, including the awareness issue, in EU member states and their national laws, which shared predominantly the Continental (civil) law tradition based on Roman law and a robust codification and belongs to the same legal family as the majority of EU members.

According to the prevailing opinion in basically all EU member states and even states out of the EU, stricter rules on a squeeze-out with requirements regarding compensation determination and ownership disclosure are considered as preferable [28]. The related EU harmonization wave induced all EU member states jurisdictions to modify their previous rules in this matter. These changes were generally welcomed by the majority of EU member states - see the Czech Republic and Czech law after the re-codification - but not by all of them. In addition, EU member states used the possibility of selecting between options offered by the Takeover Directive, and thus the harmonization was undermined in the name of national preferences. The Slovak Republic transposed the Takeover Directive by the amendment of the Slovak Security Act and it appears to be much less controversial than the original transposition in the Czech law, i.e. in the Czech Commercial Code [16]. Whether the new Czech regulation of the squeeze-out via BCA is better will be shown in the near future. In contrast, we do not need to wait regarding other EU member states. Scandinavian countries have really strong shareholder protection, but this leads to the fact that controlling shareholders "are" corporate governance [10] able to take advantage of minority shareholders. Even worse, in Spain, the squeeze-out regulation is unsatisfactory and allegedly the initiated changes have not increased minority shareholder's protection [1]. A critical voice comes from Poland as well, where there is no hesitation to speak about "expropriation" of minority shareholders and where it is suggested that this reduces the company market value [9]. However, even in Germany, where the legislation on squeeze-out is well developed and is not subject to any harsh criticism, the general experience with eternal disputes over compensation in squeeze-out is pragmatically grim. Namely, nearly all squeeze-outs in Germany are legally challenged by minority shareholders [4] (Croci, 2017), resembling the litigation trends in the USA [14]. Additional cash compensation is larger in appraisal procedures, but actions of avoidance are completed much faster. Overall, the evidence suggests that starting post-deal 
litigation by challenging the cash compensation offered in a squeeze-out delivers high returns for minority shareholders, i.e. minority investors [4]. Basically, minority shareholders in all EU member states are "surprised" by the squeeze-out and really have to fight in court for what they should have received smoothly and without any further ado by the law and to have been treated fairly, not discriminatorily. In Germany, Austria and the Netherlands, these arguments are based on general fairness. In France and Belgium, the criminal law offers assistance. Spanish and Portuguese rules are perhaps more suitable, requiring - in certain situations - that minority shareholders at disadvantage confirm the general meeting decision by a majority vote [11]. Obviously, this means that the poor application of law leads to the litigation trying to offset it and random rules from various branches of law are helpful in this matter. This is highly inefficient and unfair. Would it not be better to prevent it? Should not we help minority shareholders in the first place to avoid such a situation?

\section{Conclusion}

The squeeze-out legislation, namely the Czech BCA with respect to the squeeze-out launching and compensation, was described, the awareness of its potential of application was tested and analyzed, and the comparison was provided. Hence, all three goals were met and led to identification of a cross-border issue. The analyzed literature and questionnaire investigation confirm the significance of the squeeze-out, complexity of a balanced legislation with effective and efficient application, and suggest that the awareness of squeeze-out, especially of its physical approaching, is ambiguous, if not directly reduced; and this might have various negative impacts on the individual as well as the entire society. In the Czech Republic, there is an asymmetry of information and minority shareholders are not fully in touch with enough information, especially about the entire business and financial situation of the shareholder company, and also about the fact that other minority shareholders are approached by one shareholder desiring to reach the $90 \%$ threshold of this shareholder company. Even if they were aware of the squeeze-out requirements and regulations, they could not take the full benefit of it, because they simply did not see it coming. Similarly, issues arise when one of them succeeds with the "evening-up" judgment and other squeezed-out shareholders do not learn about this judgment and so they cannot enjoy, and possibly enforce, their right for the even treatment. In other EU member states and jurisdictions, the inefficiency of the squeezeout legislation and its interpretation and application is a serious issue as well. The minority shareholders are not sufficiently protected and, if they are protected, then they are not aware of it and cannot recognize the situation of a pending squeeze-out. Once they learned about it, they would be strongly inclined to litigate [4]. This general drive of minority shareholders to petition the court for an improved compensation, evening-up, is perhaps slightly new in continental law jurisdictions, but it is a historically well-known trend in common law jurisdictions, especially in the USA, namely in Delaware [14]. Thus, again, the state via judiciary is dragged in disputes about ill-informed minority shareholders truly squeezed-out by majority shareholders. Since, the states and laws passed the Rubicon and decided to legislatively protect them; they should make sure that this protection is real, effective and efficient, and not ephemeral and fictive. It is correctly suggested that the treatment of minority shareholders testifies about the company integrity [10] and has an impact on the perception of its products, thus it is in the interest of the company to treat minority shareholders fairly. However, in a situation of a predator seeking to get the company, it cannot be expected that he or she would change their heart due to this concern.

The presented information points out that a critical problem is the ambiguous awareness on the part of the minority shareholders about the approaching squeeze-out, which is magnified, if not caused, by an insufficient communication between minority shareholders. Minority shareholders have often a complicated, if any at all, access to information about "their" 
shareholder company and the potential inside predator, with an influential shareholder recklessly going for the majority and then exclusivity being in a stronger position and benefits by the information asymmetry, partially natural and partially perhaps pre-arranged by them. The enhancement of information is redressed and rebalances this information asymmetry and better communication between minority shareholders would undoubtedly help them to take better care and to protect their investment better. They would be able to reach more sophisticated decisions and arguably they could handle their situation and shares in such a manner so as to protect them even better that the (partially dead) letter of the BCA and other legislation. It might be suggested that both the freedom of making business decisions as well as the protection of the property of these individuals, would be achieved, consequently an indirect control against predatory "grass-hoper" shareholders would be established, ultimately supporting the entire business environment. However, even without dramatic legislative changes, the current ambiguity and information asymmetry can be addressed. Already now, the fundamental corporate documents, such as the Act of Incorporation, By-Laws, etc. allow for establishing a reinforced duty of information backed by sanctions. Since the shareholder structure can change dramatically over time, it appears advisable to set a rather low threshold launching this right, i.e. when one shareholder reaches $20 \%$, he or she has to inform all remaining shareholders... This would increase both the freedom of information and investment acting by minority shareholders; it could serve as a preventive measure against the "expropriation" by the creeping $90 \%$ shareholder as well. The law principles of the autonomy of will and of the contracting freedom allows incorporating such provisions and a mechanism in fundamental corporate documents. However, once the shareholder company is established and its fundamental corporate documents do not include such measures, the options of minority shareholders are dramatically reduced. Basically, such minority shareholders need to take the initiative and look for allies in order to improve their communication and make it more efficient, and coordinate their endeavors too. They can create informal associations or form groups, or at least take advantage of modern information technologies [19] and the social media in order to "stay in touch and pass information." Such a synchronization of efforts can increase their mutual protection as well as the protection of the entire shareholder company, discourage predatory single shareholder temptations and activities, and even help minority shareholders to exercise their other rights more effectively and efficiently, such as the rights linked to annual general meetings of the shareholder company.

The EU attempts to harmonize various aspects of shareholder company law and thus brings these jurisdictions even closer. Despite all these endeavors and the massive priority given to the single internal market and the competition within, the squeeze-out national rules and their application remain different and even face diverse challenges and are not perceived with a similar degree of satisfaction or dissatisfaction. The national implementations of the equal treatment rule are not homogenous [11] and the only common denominator is that the minority shareholders in the EU are generally "surprised", not fully informed in advance, and then they really have to fight for their rights. It is well established worldwide that reducing information asymmetry improves firms' "earnings management behavior" [6], increases effectiveness and efficiency and is beneficial for stakeholders. Hence, the above mentioned recommendations, to address the information asymmetry and to improve the co-operation of minority shareholders, and generally to go more for the prevention of potentially abusive and advantage taking squeeze-out, appears relevant even outside of the Czech Republic, i.e. basically to all EU member states and their laws. All this seems to fit the proclaimed bottomup approach as well as the philosophy of the Europe 2020 with its sustainable growth. An ounce of prevention is better than a pound of cure and knowledge is power, is it not?! 


\section{Literature}

[1] ALCADE, N.; PÉREZ-SOBA, I.: Has the EU Takeover Directive Improved Minority Shareholder Protection? The Spanish Evidence. European Business Organization Law Review. 2016, Vol. 17, Issue 3, pp. 261-283. ISSN 1566-7529. DOI: $10.1007 / \mathrm{s} 40804-$ $\underline{016-0049-8}$

[2] BANÁYIOVÁ, A.: Právo akcionářů na dorovnání - soudní judikatura ve světle nové právní úpravy. Bulletin Advokacie. 2016, Vol. 11, pp. 30-31. ISSN 1210-6348.

[3] BARTUSKOVÁ, T.; PAPAlOVÁ, M.; KRESTA, A.: Selection of a Forecasting Method: Analytical Hierarchy Process Approach. Scientific Papers of the University of Pardubice, Series D. 2015, Vol. 34, Issue 2, pp. 17-28. ISSN 1211-555X.

[4] CROCI, E.; NOWAK, E.; EHRHARDT, O.: The corporate governance endgame minority squeeze-out regulation and post-deal litigation in Germany. Managerial Finance. 2017, Vol. 43, Issue 1, pp. 95-123. ISSN 0307-4358. DOI: 10.1108/MF-012016-0032

[5] CVIK, E. D.; MacGREGOR PELIKÁNOVÁ, R.; HES, A.: The impact of recodification on the squeeze-out in a comparative perspective. In: Jedlička, P., Marešová, P., Soukal, I. (eds.), Double-blind peer reviewed proceedings of the international scientific conference Hradec Economic Days 2017. UHK, Hradec Králové, 2017, Vol. 7(1), pp. 127-136. ISBN 978-80-7435-664-3.

[6] DAI, Y.; KONG, D.; WANG, L.: Information asymmetry, mutual funds and earnings management: Evidence from China. China Journal of Accounting Research. 2013, Vol. 6, Issue 3, pp. 187-209. ISSN 1755-3091. DOI: 10.1016/j.cjar.2013.03.001

[7] DĚDIČ, J.; PIHERA, V.: Nucený výkup a cena akcií [online]. Ekonom. 25. 5. 2006 [accessed 2016-08-10]. Available from WWW: http://ihned.cz/c3-18533990-000000_dnuceny-vykup-a-cena-akcii

[8] DVOŘÁK, T.: Squeeze-out aneb má drobný akcionář důvod k pláči. Právní fórum. 2005, Vol. 7, pp. 20-30. ISSN 1214-7966.

[9] GĘBKA, B.: Ownership structure, monitoring, and market value of companies: evidence from an unusual privatization mode. International Review of Applied Economics. DOI: 10.1080/02692171.2014.918938

[10] GILSON, R. J.; SCHWARTZ, A.: Corporate control and credible commitment. International Review of Law and Economics. DOI: 10.1016/j.irle.2015.06.002

[11] GORAK, A.: The Interests of Minority and Majority Shareholders in the EU. Journal of International Affairs. 2013, No. 1, pp. 1-2. ISSN 0022-197X.

[12] HAVEL, B. et al.: Zákon o obchodních korporacích s di̊vodovou zprávou a rejstř́kem. $1^{\text {st }}$ edition. SAGIT, Ostrava, 2012. ISBN 978-80-7208-923-9.

[13] HECKMAN, J. J.: Rejoinder: Response to Sobel. Sociological Methodology. 2005, Vol. 35(1), pp. 135-162. ISSN 1467-9531. DOI: 10.1111/j.0081-1750.2006.00166.x

[14] JIANG, W.; LI, T.; MEI, D.; THOMAS, R.: Appraisal: Shareholder Remedy or Litigation Arbitrage? Journal of Law and Economics. DOI: 10.1086/689578

[15] KNAPP, V.: Teorie práva. $1^{\text {st }}$ edition. C. H. Beck, Praha, 1995. ISBN 80-7179-028-1.

[16] KOTLÁRIK, M.: Takeover Bids Directive: Board Neutrality, Breakthrough, Squeezeout and Sell-out. The Common law review. 2008, Vol. 9, pp. 28-30. ISSN 1213-4678. 
[17] MATEJKA, J. Internet jako objekt práva - Hledání rovnováhy autonomie a soukromí. CZ.NIC, Praha, 2013. ISBN 978-80-904248-7-6.

[18] PEARSON, K.: On the criterion that a given system of deviations from the probable in the case of a correlated system of variables is such that it can be reasonably supposed to have arisen from random sampling. The London, Edinburgh, and Dublin Philosophical Magazine and Journal of Science. Series 5. DOI: 10.1080/14786440009463897

[19] PELIKÁNOVÁ, R. M.: Internet My Dearest, What Type of European Integration Is The Clearest? Acta Universitatis Agriculturae et Silviculturae Mendelianae Brunensis. 2013, Vol. LXI, Issue 7, pp. 2475-2481. ISSN 1211-8516.

[20] PELIKÁNOVÁ, R. M.; CÍSAŘOVÁ, J.: An Overview of the Concept of Good Morals in Czech Codices. AA Law Forum. 2014, No. 5, pp. 3-12. ISSN 1804-1094.

[21] PELIKÁNOVÁ, R. M.; MacGREGOR, R.: Current academic and managerial views on the valuation of Internet domain names. In: Loster, T.; Pavelka, T. (eds.), $10^{\text {th }}$ International Days of Statistics and Economics. VŠE, Praha, 2016, pp.1119-1129. ISBN 978-80-87990-10-0.

[22] POSLANECKÁ SNĚMOVNA PČR; VLÁDA ČR. Dưvodová zpráva kzákonu o obchodnich korporacich. 2011. ASPI - LIT38264CZ.

[23] SHAWN, M.: Global Society and International Relations: Sociological Concepts and Political Perspectives. $1^{\text {st }}$ edition. Polity Press, Cambridge, 1994. ISBN 0745612113.

[24] SCHUMPETER, J. A.: Capitalism, Socialism and Democracy. Harper \& Brothers, New York, 1975. ISBN 0-06-13308-6.

[25] SILVERMAN, D.: Doing Qualitative Research - A Practical Handbook. $4^{\text {th }}$ edition. SAGE, London, 2013. ISSN 978-1446260159.

[26] SZYDA, J. A.: Verification of the usefulness in Implementing Discriminant Analysis Models in the Assessment of Potentially Bankrupt Businesses in the Wholesale Trade Sector within the Construction Industry. ACC Journal. 2014, Vol. XX, Issue 2, pp. 3140. ISSN 1803-9782.

[27] ŠTENGLOVÁ, I.; PLÍVA, S.; TOMSA, M. et al.: Obchodní zákoník. Komentář. $13^{\text {th }}$ edition. C. H. Beck, Praha, 2010. ISBN 9788072635825.

[28] WANG, Y.; LAHR, H.: Takeover law to protect shareholders: Increasing efficiency or merely redistributing gains. Journal of Corporate Finance. 2017, Vol. 43, pp. 288-315. ISSN 0929-1199. DOI: 10.1016/j.jcorpfin.2017.01.007 


\section{NEJEDNOZNAČNÉ POVĚDOMÍ O BLÍŽÍCÍM SE SQUEEZE-OUT - ČESKÁ PŘÍPADOVÁ STUDIE V EU PERSPEKTIVĚ}

Nucený přechod účastnických cenných papírů, neboli vytěsnění či squeeze-out, je kritizovaná právní metoda používaná akcionáři $\mathrm{v}$ EU, která byla podstatně změněna $\mathrm{v}$ rámci současné české právní rekodifikace. Nově byla zakotvena povinnost většinových akcionářu pro př́pad squeeze-out postupovat na základě stejných podmínek vůči všem minoritním akcionářùm. Tito mají obdržet stejnou kompenzaci, a případě dorovnání. Účinné uplatnění tohoto pravidla vyžaduje, aby minoritní akcionáři o něm měli povědomí. Trojice cílů tohoto příspěvku je popsat a vysvětlit předmětnou novou povinnost a poskytnout hloubkovou, kritickou a komparatistickou analýzu povědomí o blížícím se squeeze-out, které ji zakládá. S ohledem na cíle jsou stanoveny hypotézy a využity multidisciplinární primární a sekundární prameny, a to z ČR i EU. Získané výsledky s komentáři naznačují nedostatečné povědomí, které má negativní dopad na aplikaci nově uložené povinnosti v ČR a celkově in na squeeze-out situace $\checkmark$ EU.

\section{DAS AMBIVALENTE BeWUSSTSEIN ÜBER DAS NAHEN DES SQUEEZE-OUT - TSCHECHISCHE FALLSTUDIE IN DER EU PERSPEKTIVE}

Eine gezwungene Übertragung von teilnehmenden Wertpapieren, Squeeze-out, ist eine kritisierte Rechtsmethode, die in der EU verwendet wird und durch die neueste tschechische Rekodifizierung deutlich verändert wurde. Für ein Squeeze-out-Szenario wurde eine neue Pflicht der Mehrheitsgesellschafter eingeführt, und zwar mit allen Minderheitsgesellschafter in gleicher Weise zu verhandeln und gleichen Ausgleich zu erteilen. Um diese neue Regel effektiv und effizient anwendbar $\mathrm{zu}$ machen, müssen sich die Minderheitsgesellschafter dessen bewusst sein. Das Trio der Ziele dieses Aufsatzes ist, diese Pflicht zu beschreiben und zu erklären und eine tiefe, kritische und vergleichende Analyse über das Bewusstsein über die Annäherung von Squeeze-out zu schaffen. Dazu werden zusammenhängende Hypothesen und primäre als auch sekundäre multidisziplinäre Daten verwendet. Die erzielten Resultate deuten darauf hin, dass das unzureichende Bewusstsein die Anwendung der neuen verhängten Pflicht in der Tschechischen Republik und die Squeeze-outs im Allgemeinen in der EU beeinträchtigt.

\section{NIEJEDNOZNACZNA ŚWIADOMOŚĆ ZBLIŻAJĄCEGO SIĘ SQUEEZE-OUT - CZESKIE STUDIUM PRZYPADKU Z PERSPEKTYWY UE}

Przymusowy wykup papierów wartościowych, czyli squeeze-out to krytykowana metoda prawna stosowana przez akcjonariuszy w UE, która została w istotny sposób zmieniona w ramach czeskiej rekodyfikacji prawa. Nowością na wypadek squeeze-out jest obowiązek większościowych akcjonariuszy postępowania na takich samych warunkach wobec wszystkich drobnych akcjonariuszy. Mają oni otrzymać taką samą rekompensatę i ewentualnie wyrównanie. Skuteczne stosowanie tej zasady wymaga, by drobni akcjonariusze mieli tego świadomość. Niniejszy artykuł ma trzy cele, opisanie i wyjaśnienie nowego obowiązku i przeprowadzenie dogłębnej, krytycznej i porównawczej analizy wiedzy nt. zbliżającego się squeeze-out, który taki obowiązek rodzi. Pod kątem określonych celów postawiono hipotezy i wykorzystano wielodyscyplinarne źródła pierwotne i wtórne, zarówno z Czech, jak i UE. Uzyskanie wyniki wraz z ich omówieniem wskazują na niewystarczającą wiedzę, która ma negatywny wpływ na stosowanie nowo nałożonego obowiązku w Czechach i ogólnie też na sytuację squeeze-out w UE. 